\title{
ANALISIS FAKTOR-FAKTOR PENENTU PROKRASTINASI AKADEMIK DAN PENGARUHNYA TERHADAP PRESTASI BELAJAR MAHASISWA \\ (Studi Kasus Di Prodi Pendidikan Ekonomi FKIP Univ. Pamulang)
}

\author{
RUSMAINI $^{1)}$, PURWATI YUNI RAHAYU ${ }^{2)}$ \\ ${ }^{1,2}$ Dosen Pendidikan Ekonomi, Universitas Pamulang \\ dosen02066@unpam.ac.id ${ }^{1}$, purwatiyunirahayu@gmail.com ${ }^{2}$
}

\begin{abstract}
ABSTRAK
Penelitian ini bertujuan untuk mengungkapkan: 1) Faktor-faktor penentu prokrastinasi akademik mahasiswa Prodi Pendidikan Ekonomi FKIP UNPAM, 2) Faktor yang paling dominan sebagai faktor penentu prokrastinasi akademik mahasiswa Prodi Pendidikan Ekonomi FKIP UNPAM, 3) Bagaimana pengaruh prokrastinasi akademik terhadap prestasi belajar mahasiswa Prodi Pendidikan Ekonomi FKIP UNPAM. Penelitian ini menggunakan Stratified Random Sampling dalam pengambilan sampel. Sampel dari penelitian ini adalah berjumlah 166 orang mahasiswa. Teknik analisis data yang digunakan adalah: analisis factor dan analisis Regresi Berganda. Hasil penelitian adalah: 1) Hasil akhir Kaiser Meyer Olkin (KMO) menunjukkan angka 0,789 yang berada pada kategori baik. Hal ini berarti nilai Kaiser Meyer Olkin (KMO) dapat menjelaskan bahwa variabel yang menentukan prokrastinasi mahasiswa Prodi Pendidikan Ekonomi FKIP UNPAM. 2) Terbentuk enam variabel yang dapat menentukan prokrastinasi mahasiswa Prodi Pendidikan Ekonomi FKIP UNPAM yaitu (a) variabel kondisi psikologis, (b) variabel kondisi fisik, (c) variabel kondisi lingkungan, (d) variabel karakteristik tugas, (e) variabel manajemen waktu, dan (f) variabel fasilitas belajar. 3) Terdapat pengaruh yang signifikan dan negatif antara faktor penentu prokrastinasi terhadap prestasi belajar, dimana nilai signifikansi $0,000<\alpha 0,05$. Artinya tingkat prokrastinasi dapat mempengaruhi tinggi rendahnya prestasi belajar mahasiswa.
\end{abstract}

Kata kunci: Prokrastinasi Akademik, Prestasi Belajar 


\section{PENDAHULUAN}

Dalam dunia pendidikan, ada beberapa unsur yang harus dilakukan oleh pengajar diantaranya ialah pengajar mendidik, memberikan arahan, mentrasfer ilmu kepada peserta didik serta melatih keterampilan setiap individu dari peserta didik tersebut

Untuk mencapai prestasi belajar yang memuaskan mahasiswa dituntut untuk aktif dalam proses pembelajaran. Aktif secara psikomotor, pengetahuan dan dan secara tingkah laku. Implikasi dari keaktifan ini dituntut mahasiswa tidak segan-segan mengerjakan tugas belajar yang diberikan kepada mereka. Seperti terlibat langsung dalam diskusi kelompok, membuat tugas-tugas yang diberikan dan kegiatan sejenis lainnya.

Keterlambatan mahasiswa dalam mengerjakan tugas tentunya dapat menyebabkan nilai mahasiswa tidak tuntas. Perilaku terlambat atau menunda mengerjakan tugas ini seperti sudah membudaya di kalangan mahasiswa tidak terkecuali pada mahasiswa program studi pendidikan ekonomi Universitas Pamulang. Bahkan pada mata matakuliah prasyarat beberapa mahasiswa tidak lagi peduli terhadap nilai yang diperoleh. Padahal mata kuliah prasyarat merupakan mata kuliah yang sangat penting di Program Studi Pendidikan Ekonomi Universitas Pamulang.
Dalam menyelesaikan tugastugas di perguruan tinggi masih banyak perilaku mahasiswa yang tidak tepat waktu, atau menunda mengerjakan tugas sehingga tidak menyerahkan tugas yang diberikan pada waktu yang telah ditentukan. Perilaku untuk menunda-nunda pengerjaan merupakan istilah dari cabang ilmu psikologi yang biasa disebut dengan istilah prokrastinasi. Penundaan dalam mengerjakan tugas akademik disebut dengan prokrastinasi akademik. Dimana prokrastinasi akademik ialah suatu hal yang cenderung dilakukan baik disengaja maupun tidak sengaja untuk menunda pengerjaan tugas.

Berdasarkan hasil pengamatan peneliti faktor yang paling dominan dalam pembentukan prokrastinasi akademik mahasiswa adalah malas, sebesar 93,33\% (28 mahasiswa dari 30 mahasiswa) sedangkan faktor yang tidak dominan dalam pembentukan prokrastinasi akademik mahasiswa adalah tidak menyukai mata kuliah tersebut, sarana dan prasarana serta fasilitas penunjang yang kurang memadai dan pergaulan teman sebaya yaitu sebesar $16,67 \%$ atau 5 mahasiswa dari 30 responden).

Hasil pengamatan di atas didukung oleh penelitian Rusmaini (2019) yang menyatakan bahwa mahasiswa program studi pendidikan ekonomi Universitas Pamulang membutuhkan bahan ajar yang sesuai dengan standar kelayakan buku teks, 
namun bahan ajar yang tersedia sangat minim sehingga keterbatasan bahan ajar juga dapat mengakibatkan terjadinya prokrastinasi akademik.

Mahasiswa memiliki alasan
yang berbeda-beda
melaksanakan prokrastinasi. Karena
perbedaan tersebut maka peneliti
berminat untuk melakukan penelitian
dengan judul "Analisis Faktor-
faktor Penentu Prokrastinasi
akademik Akademik Dan
Pengaruhnya Terhadap Prestasi
belajar Mahasiswa Program Studi
Pendidikan Ekonomi Universitas
Pamulang".

\section{METODE PENELITIAN}

Dalam penelitian ini peneliti menggunakan metode penelitian yang bertujuan untuk mengetahui apakah ada pengaruh dari faktorfaktor penentu prokrastinasi. Dalam hal ini peneliti menggunakan metode deskriptif Asosiatif (Arikunto:2010).

Objek dalam Penelitian ini ialah mahasiswa program studi pendidikan ekonomi Universitas Pamulang. Penelitian ini akan dilaksanakan pada bulan Januari 2019.

\section{HASIL DAN PEMBAHASAN}

Hasil dari penelitian ini ialah mengetahui apa saja faktor-faktor penentu prokrastinasi akademik terhadap prestasi belajar mahamahasiswa Prodi Pendidikan Ekonomi FKIP Universitas Pamulang, dimana semua indikatornya diperoleh beberapa variabel yaitu meliputi lupa, malas, tidak mengerti, lelah pulang sekolah, asyik bermain handphone, asyik menonton, membantu orang tua, senang bermain, terpengaruh lingkungan, tidak menyukai pelajaran tersebut, mengerjakan pekerjaan rumah, moody, waktu pengumpulan masih lama, minimnya bahan ajar yang tersedia, mahasiswa lebih mengutamakan aktivitas diluar jam belajar seperti organisasi kemahasiswaan, kurang menariknya tugas yang diberikan oleh guru, padatnya aktivitas diluar kampus, kondisi kesehatan yang tidak fit, sarana dan prasarana yang kurang memadai, mahasiwa bingung untuk memulai pekerjaannya, manajemen waktu yang buruk, memiliki kecemasan, stress, kurang konsentrasi, tidak senang dengan guru mata pelajaran, rasa takut gagal. Selain itu, kurangnya pengawasan dari pihak sekolah, tidak ada hukuman (punishment), adanya toleransi dari guru, tidak ada teman untuk belajar, mudah menyerah, memandang tugas sesuatu yang berat, perfeksionis, tidak percaya pada kemampuan sendiri, bisa mencontek di sekolah, tidak ada keinginan untuk berprestasi, kehidupan yang tidak menyenangkan, kemampuan intelegensi, motivasi belajar rendah, tidak ada dukungan dari orang tua, pernah trauma dengan tugas tertentu, pernah mendapat reinforcement atas 
perilaku tersebut, dan pergaulan teman sebaya.

Tabel 1. Faktor-Faktor Penentu Prokrastinasi akademik

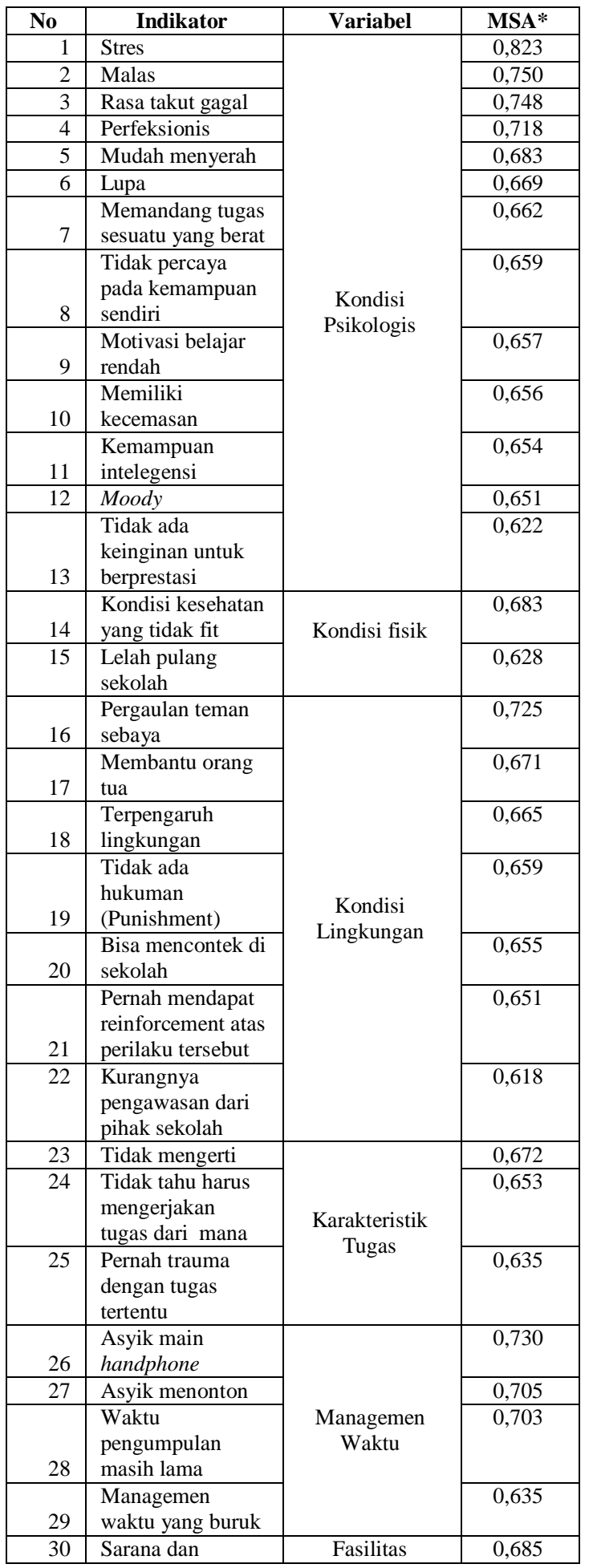

\begin{tabular}{|c|l|c|c|}
\hline & $\begin{array}{l}\text { prasarana yang } \\
\text { kurang memadai }\end{array}$ & Belajar & \\
\hline 31 & $\begin{array}{l}\text { Kurang referensi } \\
\text { dari tugas yang } \\
\text { diberikan }\end{array}$ & 0,673 \\
\hline
\end{tabular}

Tabel 2. Hasil Uji Normalitas

\begin{tabular}{|l|l|c|c|}
\hline No & \multicolumn{1}{|c|}{ Variabel } & Asymsig. & Keterangan \\
\hline 1. & $\begin{array}{l}\text { Kondisi } \\
\text { psikolologis }\end{array}$ & 0,595 & Normal \\
\hline 2. & Kondisi fisik & 0,233 & Normal \\
\hline 3. & Kondisi Lingkungan & 0,163 & Normal \\
\hline 4. & Karakteristik Tugas & 0,319 & Normal \\
\hline 5. & Managemen Waktu & 0,281 & Normal \\
\hline 6. & Fasilitas Belajar & 0,144 & Normal \\
\hline 7. & Prestasi belajar & 0,313 & Normal \\
\hline
\end{tabular}

Sumber:Hasil olahan data SPSS 2019

Dari hasil Uji Normalitas diatas diketahui bahwa semua faktor dalam penelitian ini datanya tersebar secara normal, karena setiap variabel dalam penelitian ini memiliki nilai signifikan yang lebih besar dari tingkat error 5\%. Masing-masing nilai signifikan pada faktor kondisi psikolologis sebesar 0,595, faktor kondisi fisik sebesar 0,233 , faktor kondisi lingkungan sebesar 0,163, faktor karakteristik tugas sebesar 0,319, faktor manajemen waktu sebesar 0,281, faktor fasilitas pendukung pembelajaran sebesar 0,144 dan prestasi belajar sebesar 0,313 . 
Tabel 3. Analisis Regresi Linear Berganda

\begin{tabular}{|l|c|c|c|l|}
\hline Variabel & $\begin{array}{c}\text { Koefisien } \\
\text { Regresi }\end{array}$ & $\mathbf{t}$ & Sig. & \multicolumn{1}{|c|}{ Ket. } \\
\hline Konstanta & 77,518 & 8,135 & 0,000 & - \\
\hline $\begin{array}{l}\text { Kondisi } \\
\text { psikolologi } \\
\text { s }\end{array}$ & $-0,235$ & $-5,328$ & 0,001 & $\begin{array}{l}\mathrm{H}_{\mathrm{a}} \\
\text { Diterima }\end{array}$ \\
\hline $\begin{array}{l}\text { Kondisi } \\
\text { fisik }\end{array}$ & $-0,255$ & $-5,221$ & 0,001 & $\begin{array}{l}\mathrm{H}_{\mathrm{a}} \\
\text { Diterima }\end{array}$ \\
\hline $\begin{array}{l}\text { Kondisi } \\
\text { Lingkunga } \\
\mathrm{n}\end{array}$ & $-0,177$ & $-4,234$ & 0,002 & $\begin{array}{l}\mathrm{H}_{\mathrm{a}} \\
\text { Diterima }\end{array}$ \\
\hline $\begin{array}{l}\text { Karakterist } \\
\text { ik Tugas }\end{array}$ & $-0,173$ & $-4,338$ & 0,001 & $\begin{array}{l}\mathrm{H}_{\mathrm{a}} \\
\text { Diterima }\end{array}$ \\
\hline $\begin{array}{l}\text { Manageme } \\
\mathrm{n} \text { Waktu }\end{array}$ & $-0,321$ & $-3,998$ & 0,010 & $\begin{array}{l}\mathrm{H}_{\mathrm{a}} \\
\text { Diterima }\end{array}$ \\
\hline $\begin{array}{l}\text { Fasilitas } \\
\text { Belajar }\end{array}$ & $-0,254$ & $-4,510$ & 0,002 & $\begin{array}{l}\mathrm{H}_{\mathrm{a}} \\
\text { Diterima }\end{array}$ \\
\hline
\end{tabular}

Sumber:Hasil olahan data SPSS 2019

Tabel 4. Hasil Uji F

\begin{tabular}{|c|c|c|c|}
\hline Model & F & Sig. & Ket. \\
\hline Regresi & 155,064 & 0,000 & Ha Diterima \\
\hline
\end{tabular}

Dari hasil Uji $F$ diatas, diketahui bahwa nilai sig 0,000 lebih kecil dari tingkat error 5\% $(0,05)$. Maka dari itu berarti kondisi psikologis, kondisi fisik, dan kondisi lingkungan, karakteristik tugas, managemen waktu, dan fasilitas pendukung belajar secara bersamasama mempengaruhi prestasi belajar mahasiswa Prodi Pendidikan Ekonomi FKIP Universitas Pamulang.
PEMBAHASAN

Faktor - faktor penentu prokrastinasi akademik akademik mahamahasiswa Prodi Pendidikan Ekonomi FKIP Universitas Pamulang

Berdasarkan hasil pengamatan awal peneliti mengenai faktor penentu prokrastinasi akademik akademik mahamahasiswa Prodi Pendidikan Ekonomi FKIP Universitas Pamulang terdiri dari 43 faktor namun setelah dilakukan analisis faktor, faktor-faktor penentu prokrastinasi akademik akademik mahamahasiswa Prodi Pendidikan Ekonomi FKIP Universitas Pamulang berjumlah 31 faktor yang terdiri dari 6 variabel yaitu (a) variabel kondisi psikologis yang terdiri dari faktor (1) Stres (2) Lupa, (3) memiliki kecemasan, (4) Malas, (5) Rasa takut gagal, Kemampuan intelegensi, (7) Moody, (8) Mudah menyerah, Memandang tugas sesuatu yang berat, (10) Perfeksionis, (11) Tidak percaya pada kemampuan sendiri, (12) Tidak ada keinginan untuk berprestasi dan (13) motivasi belajar yang rendah. (b) variabel kondisi fisik yang terdiri dari faktor (1) faktor kondisi badan tidak fit membuat mahamahasiswa lebih suka melakukan perilaku prokrastinasi akademik dan (2) lelah pulang sekolah. (c) variabel kondisi lingkungan yang terdiri dari faktor (1) Pergaulan teman sebaya, (2) Membantu orang tua, (3) Terpengaruh lingkungan, (4) Tidak ada hukuman (Punishment), (5) Bisa 
mencontek di sekolah, (6) Pernah mendapat reinforcement atas perilaku tersebut, dan (7) Kurangnya pengawasan dari pihak sekolah. (d) variabel karakteristik tugas yang terdiri dari faktor (1) tidak mengerti, (2) tidak tahu harus mengerjakan tugas dari mana, dan (3) pernah trauma dengan tugas tertentu. (e) variabel manageman waktu yang terdiri dari faktor (1) Pengelolaan waktu yang kurang baik, (2) suka main handphone, (3) suka menonton, dan (4) Manajemen waktu yang buruk. Dan terakhir (f) variabel fasilitas belajar yang terdiri dari faktor (1) Kurang referensi dari tugas yang diberikan,dan (2) Ketersediaan Sarpras kurang tersedia.

Hal ini sejalan dengan teori yang dikemukakan oleh Westervelt (2006), terdapat 18 ciri-ciri dari terbentuknya penundaan dalam mengerjakan tugas, yaitu perlawanan, (2) kebosanan, (3) takut gagal, (4) perfeksionis, (5) keraguan (tidak bisa memutuskan), sindrom menit terakhir, kurangnya motivasi untuk mengerjakan tugas, (8) ketakutan untuk sukses, (9) kurangnya keterampilan, (10) pemberontakan dan perlawanan, (11) merasa tidak mampu, (12) tidak bisa diatur, (13) kebingungan, (14) malu, ketidaknyamanan, (16) keangkuhan, kebencian (17) kebiasaan, dan (18) menyukai batas waktu terakhir. Selanjutnya Gerungan (2004) menjelaskan bahwa penyebab terjadinya prokrastinasi dipengaruhi oleh sembilah faktor, diantaranya ialah: 1) penggunaan waktu yang kurang baik, 2) kurang fokus dalam berkonsentrasi, (3) adanya ketakutan dan kecemasan, 4) tidak rasionalnya keyakinan yang dimiliki, 5) adanya masalah individual, 6) timbul rasa bosan, 7) harapan tidak sesuai dengan kenyataan, 8) ingin yang sempurna, dan 9) takut gagal.

\section{Faktor yang paling dominan sebagai faktor penentu prokrastinasi akademik mahasiswa Prodi Pendidikan Ekonomi FKIP Universitas Pamulang \\ Berdasarkan hasil}

communality diperoleh hasil bahwa peranan dimensi yang terbessar adalah faktor stres dengan nilai communality sebesar 0,815 . atau sebesar $81,50 \%$, hal ini berarti bahwa faktor stres mempunyai peranan yang besar penentu prokrastinasi akademik mahasiswa Prodi Pendidikan Ekonomi FKIP Universitas Pamulang, dalam hal ini juga dinyatakan bahwa mahasiswa yang memiliki stres yang tinggi akan meningkatkan prokrastinasi akademik dan menurunkan prestasi belajar mahasiswa. Dan peranan yang terkecil adalah faktor penentu kurangnya pengawasan dari pihak sekolah sebesar 0,461 ataru 46,10\%.

Hal ini berarti kurangnya pengawasan dari pihak sekolah tidak memberikan peranan yang besar dalam penentu prokrastinasi akaademik mahasiswa terhadap 
prestasi belajar pada Prodi Pendidikan Ekonomi FKIP Universitas Pamulang.

Pengaruh Prokrastinasi Akademik Akademik Dengan Prestasi Belajar Mahamahasiswa Prodi Pendidikan Ekonomi FKIP Universitas Pamulang

Berdasarkan uji hipotesis diperoleh hasil, bahwa prokastinasi akademik yang terdiri dari variabel kondisi psikologis, kondisi fisik, kondisi lingkungan, karakteristik tugas, managemen waktu dan fasilitas pendukung pembelajaran memiliki pengaruh yang terhadap prestasi belajar mahamahasiswa Prodi Pendidikan Ekonomi FKIP Universitas Pamulang. Pernyataan ini dibuktikan melalui nilai Sig pada analisis regresi berganda lebih kecil dari tingkat error (5\%), hal ini berarti bahwa tinggi rendahnya tingkat mahasiswa dalam menunda mengerjakan tugas maka akan berdampak pada indeks prstasi akademik mahasiswa.

\section{KESIMPULAN}

Kesimpulan dari penelitian ini ialah:

1. Hasil akhir Kaiser Meyer Olkin (KMO) menunjukkan angka 0,789 yang berarti baik. Hal ini berarti nilai Kaiser Meyer Olkin (KMO) dapat menjelaskan bahwa faktor yang menentukan prokrastinasi akademik mahasiswa Prodi Pendidikan
Ekonomi FKIP Universitas

Pamulang

2. Terbentuk enam variabel yang dapat menentukan prokrastinasi akademik mahamahasiswa Prodi Pendidikan Ekonomi FKIP Universitas Pamulang yaitu (a) variabel kondisi psikologis, (b) variabel kondisi fisik, (c) variabel kondisi lingkungan, (d) variabel karakteristik tugas, (e) variabel manajemen waktu, dan (f) variabel fasilitas belajar.

3. Terdapat pengaruh yang signifikan dan negatif antara faktor penentu prokrastinasi akademik. Artinya apabila mahasiswa memiliki intensitas yang tinggi dalam menundanunda pekerjaan maka prestasi yang ia dapatkan semakin menurun, begitu pula sebaliknya jik intensitas menunda pekerjaan rendah maka prestasipun akan meningkat.

\section{REFERENSI}

Arikunto.S.(2002). Proses Belajar Mengajar. Jakarta: PT Bumi Aksara

Gerungan, W.A. (2004). Psikologi Sosial. Bandung: PT Refika Asitama

Rusmaini. (2019). Implementation Of Basic Teaching Materials in The Students of Faculty of Education And Science At Pamulang University. Jurnal Ilmiah Humanika. Vol 2 No. 3. 
Westervelt, P., D. B. Trowbridge, L.G. Epstein, B. M. Blumberg, Y. Li, B.H. Hahn,G. M. Shaw, R.W. Price, and L. Ratner. (2006). Macrophage Tropism Determinants of Human Immunodeficiency Virus Type 1 In Vivo. J. Vol. 66(4) : 2577-258 